\title{
Review Article: Anthropology and the Biblical Exile.
}

Interpreting Exile: Displacement and Deportation in Biblical and Modern Contexts by Brad E Kelle, , Frank Ritchel Ames and Jacob L. Wright (eds), (Ancient Israel and Its Literature, 10; Atlanta, GA: Society of Biblical Literature, 2011), pp.xiv+464. Several figures. \$57.95. ISBN 978-1-58983-604-4; e-ISBN 978-158983-605-1.

Ethnicity and the Mixed Marriage Crisis in Ezra 9-10: an anthropological approach by Katherine E Southwood, Oxford: Oxford University Press.

Over the past three decades there have been a few attempts to use social anthropology to explore the Old Testament (OT) and interdisciplinary studies of this sort are now becoming more mainstream. Historical and archaeological data concerning ancient societies are necessarily limited in scope, and anthropological comparisons may offer insights into historical peoples who cannot be observed. In the 1970s, for my PhD on marriage and family in the OT (Bigger, 1974), I used social anthropology on marriage and family before it was fashionable to do so. One problem was that anthropologists knew biblical material (such as levirite marriage) and might read this into their fieldnotes. There were also misconceptions about anthropology in biblical studies based on now outmoded Victorian evolutionism (for example that matriarchy preceded patriarchy in evolutionary development) which contaminated biblical studies until the 1960s. Conversely, anthropologists have commented on biblical material from their own perspective, no one at greater length than Mary Douglas whose books $(1966,1993,1999$, 2004) and articles on the Pentateuch provide a substantial contribution to knowledge. She viewed the Bible as a cultural artefact, with clear functions in cultural and political life. She focused on the 'finished text' (insofar as text scan ever be described as finished, since variations are found even in scribed texts) existing in post-exilic times, seeking its social functions, political motivation and cultural meanings. Though her work is not without issues (Klawans, 2003, Lemos, 2009), it marked a revolutionary turn in OT scholarship.

This was a perspective different from approaches then used in OT scholarship - historical (heavy with source criticism), literary (focusing on the coherence of the story) and theological approaches (exploring doctrine and belief). Robert Alter's textual readings (1981) from a literature perspective provide another cog in developing a new approach. Studying the final text (that is, the preserved text) can no longer be regarded as a conservative (Christian or Jewish) strategy to expound scripture, but has the potential to be the bearer of radical interpretations, not connected with beliefs today about scriptural authority 
(though the question of why and when ancient Jews and Christians adopted these books as their scriptures is an interesting one). OT study has to resist the conceptual interference of modern Jewish or Christian theologising: some aspects of these texts will make uncomfortable reading for conservative expositors. I designed and edited Creating the OT: the Emergence of the Hebrew Bible (Bigger, 1989) with contributions by members of the Society for OT Study, as an holistic critical study of the OT preserved texts, studied for meaning rather than for origins and sources. Study of sources remains important, but is not scholars' only concern. Most recently, Yoram Hazony (2012) helpfully reads the preserved text as philosophy.

This is by way of introduction to the two books reviewed here, on the Babylonian Exile starting in 586BCE. To simplify the OT timeline, the southern kingdom of Judah was invaded and defeated by the Babylonians and some were taken into exile, maybe to create a migrant workforce, and perhaps to break up local rebellions. Over time, the Persians took over from the Babylonians and began a policy of returning exiles to their homeland. This was not altruistic but a plan to place elites with Persian values in regional government. Nevertheless, the religious were grateful, to the extent of Second Isaiah calling the Persian king Cyrus 'God's Messiah' (Isa 45.1). The province concerned was Yuhud - the terms Jews or Judaeans were not yet used or appropriate. The detailed historical issues and problems of this period have become the subject of recent research (for example Becking \& Korpel (1999), Grabbe (2004), Lipschits \& Oeming (2006)), showing that historical realities are far less certain than was previously presumed. We cannot assume that the book of Ezra is an accurate chronicle of events, but need to compare its account with what we know from elsewhere.

The two books reviewed here focus on the exile in Babylon and subsequent return, a pivotal story in the OT and both include anthropology in their interdisciplinary mix. It is a major problem that OT history writing says very little about the exile: its chronology breaks at the fall of Jerusalem (the beginning of the exile) and continues again only after the return. We are left to wonder about the purpose of pre-exilic historiography - the books of Samuel and Kings present most monarchs as flawed. Why were authors of pre-exilic histories (note that these authors were themselves not pre-exilic, since they end their story at the start of the exile) so obsessed with idolatry and therefore so down on the northern kingdom? Why is the account so negative, condemning most kings in one way or other? The writers' purpose was certainly not to praise. On the exile itself the OT maintains silence. Why? Equally, what was the purpose of the post-exilic narratives (Ezra and Nehemiah) and who wrote them? 
Just as the brothers Grimm reacted to loss of German independence by collecting traditional German stories, so it is often assumed that exiled groups collected what they could in case it became lost. Though this is possible, it is by no means certain and is unlikely to have been so simple. The account of the incompetent monarchy that we call the Deuteronomic History has a political agenda from within or beyond the exile. The Babylonians, and later the Persians, had a vested interest in not depicting preexilic times as a golden age and encouraging nostalgia. The religious orthodoxy (including the priests) also had an interest in depicting idolatry as a contributor to the disaster; undoubtedly syncretism was found in exile, as it was in the contracts of the Yuhudite military colony in Elephantine, Aswan, in Egypt (Porten, 1968). Other documents contain their own uncertainties. Genesis authenticates the tribe of Ephraim, and hence the northern kingdom. Why? Pentateuchal source criticism dates the late editorial strand $(P)$ to the exile on the grounds that its creation story reflected the Babylonian story, and covenant declarations sealed the Jews as the chosen people: however, what once was held to be certain is now not. Scholars argue about which material was written before the exile; but the compilation of texts may have gained momentum from the exile. The books of Ezra, Nehemiah and Chronicles come from a later period, offering a new 'take' on Hebrew history including the return from exile. Scholars have to separate possible fact from legend or fiction (Esther, for example), and be open to the possibility that it is all fiction.

So how are we to understand the exile? Of the two books reviewed here, one is multi-authored (23 authors) and the other single-authored, a development of a doctoral thesis. Both draw on approaches that are not commonly found in biblical studies until now, some of which (those relevant to my title) I explore here.

The first (edited by Kelle, Ames and Wright (2011) is based on 23 papers from the SBL Warfare in Ancient Israel Section. This paper explores general principles rather than specifics, especially the use of disciplines such as anthropology and sociology in our construction of the biblical exile. The introduction by Kelle sets the agenda of interdisciplinary approaches with the question, Does the modern experience of population displacement illuminate the Babylonian exile? Part 1, Archaeology and History, takes a critical look at this data, ending with a minimalist view of exile (Becking) in which the numbers going into exile were viewed as small. Archaeology is used to dismiss the "empty land" claim (Lipschits), emphasizing that many were left behind, and that the return from exile of necessity displaced local people. Population decline was also examined in sixth century BCE Judah' (Faust). Two chapters explore the nature of war booty as relevant to the fall of Jerusalem. One chapter (Burke) explores whether an 
anthropological model for refugees is relevant to the data. Part 2, Sociology and Identity argues that trauma encourages new senses of identity. Two papers (by Maier and Homan) compare the biblical situation with the destruction and restoration of New Orleans. One emphasis is on 'revived memory'. Comparisons are also made with the displaced of Sudan (Holton) with Kamya studies the effect of displacement on children there. Part 3 Psychological and Trauma starts with Smith Christopher's pioneering and much quoted use of trauma studies to illuminate the biblical exile - 'Reading War and Trauma: Suggestions Toward a Social-Psychological Exegesis of Exile and War in Biblical Texts'. Exile would certainly be traumatic, and our understanding might be enhanced by studying modern refugees. Morrow wonders if the genocidal thinking in Deuteronomy is linked to this sense of trauma; Carr finds trauma in prophecy, wondering why there are so few details of exile in the writings; Harber considers the vocabulary of trauma; and Rumfelt explores the need for narratives to repair trauma. Part 4, Text and Comparison explores texts which are rooted in the trauma of exile (Balentine and Sharp) including Ezekiel's hypermasculinity (Lemos, on Ezekiel 16 and 23). Three chapters, not relevant here, draw on wider cultural studies.

An assumption is being made that the biblical exile was like the trauma of slavery, or Sudanese displacements or natural calamities as in New Orleans. Generalisations can be made about human feelings in times of disaster, but each circumstance is different and each human response is unique. We may find that we are reduced to stating the obvious: trauma causes psychological dislocation and clinical stress. We need to know more about what the exiles did in Babylonia, where they lived and what local power they were given if we are to even begin to make secure comparisons. Comparative studies may put some psychological 'flesh' on the bare bones of history, but unless we have the bare bones correct, we invite misreadings. That the books of Ezra and Nehemiah were written in trauma and not many years later is itself an assumption.

The second book, by Southwood, is detailed and well-argued (based on her PhD thesis) focusing on a particular OT episode, the demand by Ezra that men 'put away' their 'foreign' wives. Southwood, attempting to understand the state of mind of the returned exiles, studied the anthropological literature relating to return migrants to see if this sheds light on the social attitudes and issues of this period, viewed through the literature of ethnicity and hybridity. The issue she wishes to consider is what is going on in Ezra 9-10, where Ezra the scribe (a hard-headed politician) loses his head to religious contrition and revival, weeps, wails and demands that men put away (without ceremony) their 'foreign' wives. On the one hand there are historical questions. Did Ezra really do this, or was it a crude story 
about him? Whatever happened really, we can only be certain that the account was written, whether contemporary reportage (unlikely), or later historical fiction.

For Southwood the anthropological literatures of return migration and ethnicity shed light on potential feelings and attitudes during the exile and return. Emphasis is placed on the boundary between 'us' and 'others' which is characterised by ambiguity, anomaly and social pressures. This betwixt and between (p.30, Turner, 1967) is a middle place of creative dialogue and exploration (Leech, 1969, Bhabha, 1993), leading perhaps to hybridity which might be used as a stigmatising insult (pp.182ff). Migration does not create ethnicity but can have a profound influence on it. The homeland remembered is not real but an idealisation, so return can be disappointing. Migrant communities can experience pressure to assimilate or resistance to assimilation: in either case, social realities will be altered. This new situation influences marriage, religion and the rewriting of history, all relevant to the period of Ezra: in marriage, pressures might favour endogamy (in-group marriage) rather than exogamy (intermarriage); religious revival may happen as a reaction against religious 'otherness'; and history may become represented in forms favourable to the ethnic audience, particularly in placing blame on others. Southwood recognises (p.216) that the Ezra chapters have a pronounced emphasis on ethnicity in their championing of the 'children of exile' in opposition to the 'people of the land' and recognizes the role of the author in expressing this. The author of Ezra criticises the returnees for their intermarriages. It is clear that intermarrlage was an attractive strategy to build common ground with the local people, many of whom may have been distant relatives in that their ancestors had avoided exile and remained. The local attitudes to syncretism were no different than found before the exile, which had brought on prophetic condemnation. The prejudice against ethnic difference (and hence rejection of intermarriage) affirms the existence of a privileged group, claiming to be returned exiles, with a Yahweh alone theology and hegemony enough to annul marriages and sweep aside inheritance implications, thereby producing an introspective exclusive group. We are given no idea of when this might apply, or whether it is real or ideal, but the author hereby roots this exclusivity in the historically improbable words of Ezra.

In the post-exilic period, intermarriage was common, perhaps because the returned administrators were male and may have moved without families. The books of Ezra and Nehemiah themselves reveal that many men had 'foreign' wives (that is local but with different ethnicity), so that prior to this crisis of conscience, intermarriage had not been considered a particular problem. The Yuhudites in Elephantine married local women according to their marriage contracts (Porten, 1968). Ezra's opposition to intermarriage was therefore an odd event. The numbers of men who sent their wives away (the 
implication is without divorce, declaring the marriage never to have been valid) seems small in relation to the whole population, so this is likely to be a sectarian action, the creation of a closed 'club'. The first return migrants had happily married local women without fear of contamination. Intermarriage only seems to be a problem within this Ezra story, not as a natural consequence of attitudes to ethnicity but as a deliberate and political act against syncretism.

The biblical author wrote this story for some theological and political purpose, for which characters and their motivations are constructed. 'Return migrants' may have been coming to a homeland that they had romanticised but never known (that is, it was their grandparents who were exiled) but there are other possibilities. We have to doubt whether the writer had genuine access into Ezra's mind and motivations. Our critical analysis needs to identify and explain the writer's purpose, motivations and attitudes, leaving open the question of whether the story is historiography or fiction. The time of trauma may have been long past. The central theme of withdrawal from contamination by idolatry is the starting point, a proto-sectarian demand that is seen later in Hasmonean and Essene attitudes (p.218). There is a growing literature on sectarianism (Chalcraft, 2007; Schwartz, 2010), as Southwood recognizes (pp.108-110). The writer might not have been a return migrant at all but a later sectarian revivalist projecting the religious revival back into the past and attributing the idea to an influential historical figure - effectively a pseudonymous attribution. More generalised experience of war and exile may have fed a process of ethnic inclusivity over time, which developed into sectarianism.

Those of us fortunate enough to have lived in peace forget that conflict and war have been a common human experience both in ancient and modern times, and that Bible authors and early readers were to some degree on a conflict footing, whether their belligerents were Assyrians, Babylonians, Persians, Greeks or Romans. Themes such as guilt, despair, hope and resistance are likely to be common. Ethnicity is a marker or who counts as 'us' as opposed to 'them'. Women are constant victims of war, through rape, forced marriage, homelessness, bereavement or economic oppression. The Ezra narrative victimizes the so-called 'foreign' wives, casting them off as though their marriages never existed. They were, like Eve, considered to be the originators of sin. This is done in the name of the true faith.

Both reviewed books deserve to be taken seriously. They raise the serious question of how to read the Bible in the light of human experience, as researched through anthropology and sociology. The scholar needs however to distinguish between the writers, the subjects of their writings, and the implied audience. The Babylonian exile has been given exaggerated prominence in the OT story, yet almost no accounts exist about life in exile. Bible writers have used exile in a number of ways, especially to 
demand avoidance of religious contamination. The same demand is found in Deuteronomy and the Deuteronomic History, and in the Covenant, Holiness and Priestly Codes. Despite centuries of study, precisely how biblical books emerged after the exile remains uncertain.

The use of social anthropology is not a magic bullet to fill gaps: the biblical scholar needs more than superficial comparisons. Anthropology explores how specific humans have responded to life experiences and generalisations are difficult. We have to hypothesise patterns of human thinking before science, philosophy and rational education, when causation (of disease, misfortune, war, death) seemed deliberate and remedies were needed to counter human or mythic malice. We can have more confidence that human emotions, of trauma, loss, bereavement, confusion, as well as love and loyalty, are likely to remain recognizable - but we have to be careful that our glasses are not too rose-tinted. We know even from modern warfare that humanity as a species can horrify and terrify. The anthropology of trauma and migration therefore provide useful tools if used cautiously.

\section{References}

Alter, Robert, (1981), The Art of Biblical Narrative London: George Allen \& Unwin..

Becking Bob \& Marjo C.A. Korpel (1999), The Crisis of Israelite Religion: Transformation of Religious Tradition in Exilic and Post-Exilic Times Leiden: Brill

Bhabha, Homi (1993), The Location of Culture London: Routledge

Bigger, Stephen F. (1974) Marriage and Family in the Old Testament: a study in social history and social anthropology. PhD, Manchester University, 1974

Bigger, Stephen F. (ed.) (1989) Creating the Old Testament: The Emergence of the Hebrew Bible, Oxford: Basil Blackwell

Chalcraft, David J. (ed.) (2007) Sectarianism in Early Judaism: Sociological Advances London/Oakville: Equinox

Douglas, Mary (1966) Purity and Danger, London: Routledge.

Douglas, Mary (1993/2004) In the Wilderness: the Doctrine of Defilement in the Book of Numbers, Oxford: Oxford University Press.

Douglas, Mary (1999) Leviticus and Literature Oxford: Oxford University Press.

Douglas, Mary (2004) Jacob's Tears: the Priestly work of reconciliation, Oxford: Oxford University Press. Grabbe, Lester L (2004), A History of the Jews and Judaism in the Second Temple Period, London: T\&T Clark Hazony, Yoram (2012) The Philosphy of Hebrew Scripture Cambridge: Cambridge University Press. 
Klawans, Jonathan (2003) Review Essay Rethinking Leviticus And Rereading Purity and Danger, AJS Review 27:1 (2003), 89-102.

Leech Edmund (1969) Genesis as Myth and Other Essays, London: Cape.

Lemos, T. M. (2009) The Universal and the Particular: Mary Douglas and the Politics of Impurity, The Journal of Religion Vol. 89, No. 2, April pp. 236-251.

Lipschits Oded \& Manfred Oeming (2006) Judah and the Judeans in the Persian Period, Winona Lake, Ind: Eisenbrauns

Porten, Bezalel (1968) Archives from Elephantine: the Life of an Ancient Jewish Military Colony, Berkley: University of California Press.

Schwartz, Joshua (2010) Review of Joseph Blenkinsopp, Judaism, the First Phase: The Place of Ezra and Nehemiah in the Origins of Judaism, (Grand Rapids: Eerdmans, 2009) in RBL (Society of Biblical Literature) available at http://www.bookreviews.org/pdf/7402_8068.pdf.

Turner, Victor W. (1967) "Betwixt and Between: The Liminal Period in Rites de Passage." The Forest of Symbols: Aspects of Ndembu Ritual. Ithaca, NY: Cornell University Press, 93-111. 